\title{
THE INFLUENCE OF CATTLE WASTES ON DEGRADED SAVANNA SOILS OF KWARA STATE NIGERIA
}

*ORIOLA, E.O. ${ }^{1}$ and HAMMED, A.T. ${ }^{2}$

DOI:http://dx.doi.org/10.4314/ejesm.v5i3.8

Received 5th May 2012; accepted 21st May 2012

\begin{abstract}
This paper examines the effects of cattle wastes on degraded savanna soils of Kwara State, Nigeria. A total of 40 soil samples were systematically collected from five quadrats of $12 \mathrm{~m} x$ $12 \mathrm{~m}$. In 4 identified cattle sheds and 1 in adjacent fallow land (control field) on the same soil, climatic type and ecological zone. Standard laboratory techniques were used to test soil fertility indices on each of the sites. Coefficient of variation was used to established variability or otherwise within the data set. Student's ' $t$ ' test was used to determined the significant difference in the means of soil samples collected from cattle sheds and that of the control field. The result of the laboratory test revealed that animal wastes affect the soil properties. Generally, the physical properties of the soil in this area are homogenous but variations exist in the chemical properties which fundamentally determined soil fertility and crop yield. At the end, it was clear that the fertility status of the soils is higher in the abandoned cattle sheds than those of the adjacent control field. It is therefore important for the government to provide adequate awareness and educate people on adoption of mixed farming and land use and soil properties because they tend to affect each other. Fulani nomads and arable farmers should be encouraged to co-exist harmoniously with farming communities as this would encourage sustainable crop production in low to moderate fertile soils of the tropics. And in those areas that are adversely degraded the nomads should be made to colonize such environment so as to help in rejuvenating the soils of such area.
\end{abstract}

Keywords: Cattle wastes, Soil, fertility status, rejuvenation, nutrient, properties, mixed faming.

\section{Introduction}

Soil as a component of landscapes occupies a central position in the landscape balance due to its diverse functions. It constitutes a dynamic system within which a series of changes (Addition, losses, modification and alterations) constantly occur. These changes directly affect the composition, properties and productive potentials of the soils (Akinbode, 1986).

Pimentel et al (1993) estimated that global food production is 15-30 percent lower as a result of various effects of soil degradation. The implication of this low soil productivity is that most nations found in this situation will resort to food importation. For instance, Nigeria, with an estimated 71.2 million hectares of cultivated land and $78 \%$ of her population engaged in agricultural activities, has not been able to feed her teaming population adequately. Between 1981 and 1985, the country spent a total of N7.75 million on importation of agricultural products (Oriola, 2004).

In many low-income countries, particularly in sub-Saharan African, yields have stagnated in recent years. While additional land is still available to be brought into food production, in most countries it is marginal land with lower productivity. These trends imply that for most food-insecure countries, constraints on land area and quality will play an increasingly important role in determining food security in the future.

Beside the characteristics vagaries of climate, part of the problem is due to soil condition and land productivity which has serious implication on agricultural output. Hence, there is a need for adoption of adequate soil management practices as a panacea for improved, increased and sustained agricultural production.

\footnotetext{
${ }^{I}$ Department of Geography \& Environmental Management University of Ilorin, P.M.B. 1515, Ilorin, Nigeria.

${ }^{2}$ Standard Organizationof Nigeria, Operational

Headquarters, Lagos, Nigeria

*Corresponding author email: lolaoriola@gmail.com
} 
On the nature of soil and fertility improvement both during and after cropping, several suggestions have been given. These range from the use of chemical fertilizers, green manure, farm yard manure, and practice of bush fallowing system (Nwinyi, 1981; Aina, 1982 and Aweto, 1981). These authors have reported the significant roles of fallow on soil condition.

This paper therefore examines the properties of soils under Fulani cattle shed in Asa L.G.A. of Kwara State with a view to assess the effects of the cattle wastes on the soil and the implications for soil fertility. This will assist in the management and conservation of tropical soils under pastoral activities.

\section{Study Area}

This study was carried out in Asa local government area of Kwara State, Nigeria. This Local Government is located on Latitude $08^{0}$ $00^{\prime}$ and $09^{\circ} 10^{\prime}$ North and longitude $04^{0}$ 15 'east of the ridian (Kwara State Ministry of land and Housing, 2003). It stretches from the peri-urban fringes of the city of Ilorin to the northern boundary of Oyo State. It also shares boundaries with Oyun L.G.A., Kwara State (Fig 1).

The area is under-laid by pre-Cambrian basement complex rock of porphyritic granite. This type of rock has undergone many processes of metamorphism and magmatite intrusion. It is mainly drained by River Asa on which we have Asa Dam and other rivers that drained into the Asa River. These include Ohon, Bina, Jiya Molete and Afon.

The climate is characterised by the alternation of wet and dry seasons. Each lasting about six months. The wet season usually starts from May to October. Rainfall ranges between $1000 \mathrm{~mm}-1,500 \mathrm{~mm}$ during the period. The dry season commences November and lasts till early March (Oyegun, 1983). The average monthly day time temperature ranges from $24.8^{\circ} \mathrm{c}$ in wet season and $29.4^{\circ} \mathrm{c}$ in dry season (Oyebanji, 1993).

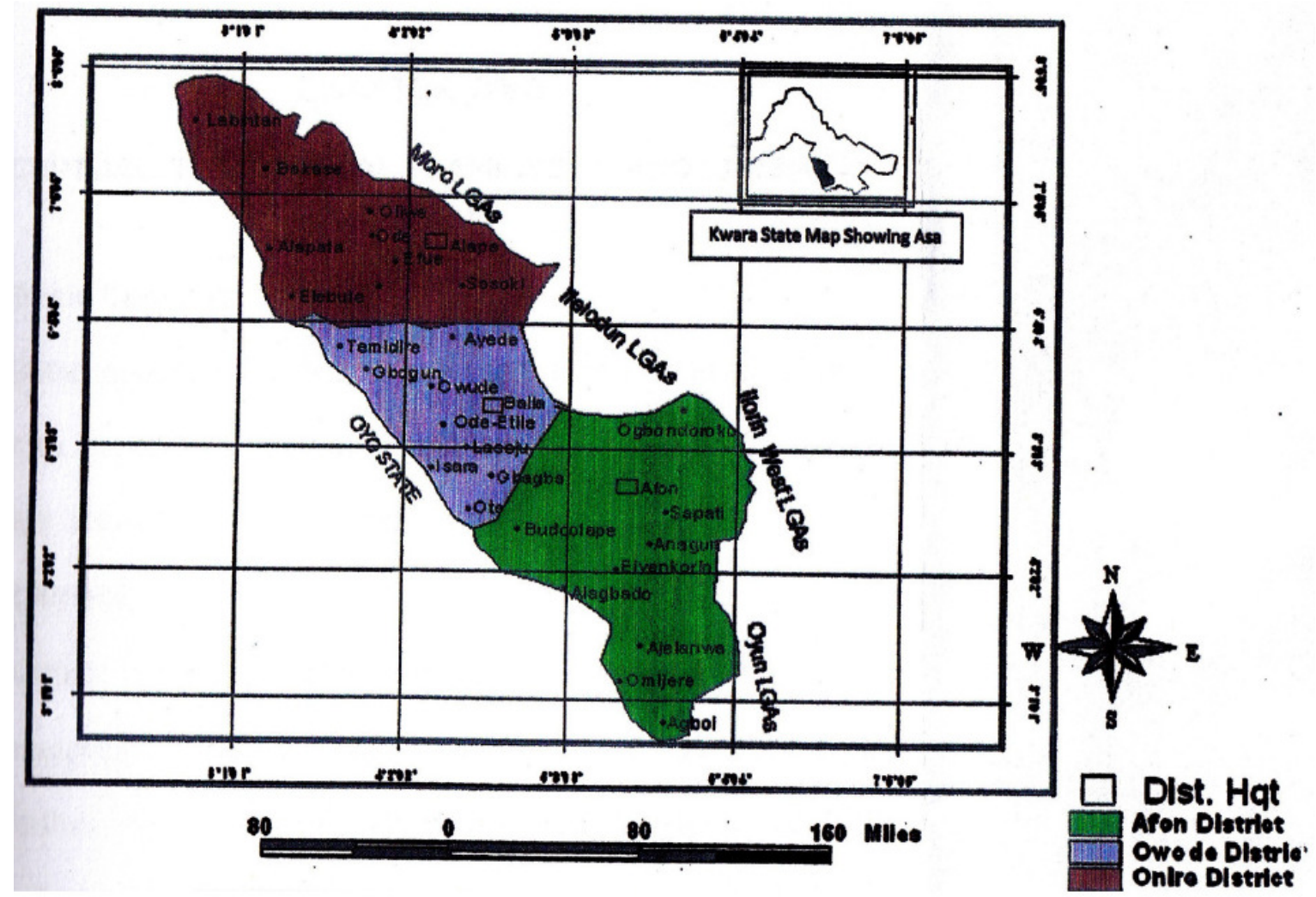

Figure 1. Map of Asa Local Government Area.

Source: Jeje (2011). 
The soil type in Asa L.G.A. is ferruginous tropical soil types existing on a crystalline acidic rocks. The soils are uniform in terms of physical characteristics. The fertility of soils is variable and farming activities are enhanced in most parts of the study area. Much of the land in this area has been debased by cultivation and burning which has implication on its fertility and productive potentials. Thus, it demands for adequate soil management to attain better productivity.

The vegetation is wooded savannah grass land or derived savannah because the original vegetation cover has been removed through human activities such as clearing and cattle grazing among others. The common trees are locust bean tree (Parkia biglobosa) and shear butter tree (Vitalera paradosa); while the grains grown in the area include millets, maize, sorghum and rice. Common root crops found in this area are yam, cassava, potatoes and cocoyam.

\section{Material and Methods}

In Asa Local Government area of Kwara state, Fulani cattle sheds were located. These cattle sheds are farmsteads in which cattle are kept. It is a fence-like structure constructed with woods usually about $100 \mathrm{~m}^{2}$ in size. It is also an open surface exposed to various climatic elements such as rainfall, insolation and humidity among others. The surface is littered with cow dung and fallen leafs. Some scattered shrubs are also found on the surface. The presence of cattle has prevented the growth of vegetation and a shed harbours about 200 heads of cattle. On adjacent land, often a considerable distance from cattle shed, the area is occupied by common grasses such as Elephant grass (Afzelia africana), stubborn grass (Soberlinia doka) and Bahama grass (Parkia clappertonima) and is undergoing fallow process.

The study site consists of two different land surfaces; cattle shed and normal fallow land. Soil samples were taken from abandoned cattle shed. It was termed 'abandoned' because cattle had been relocated from the surface two years ago, after about three years of intensive invasion and habitation. It should be noted that a section of Ilorin are of Fulani tribe. The site was selected because of anticipated soil materials reactions to cattle wastes in this environment. On each surface, 20 soil samples were collected from $12 \mathrm{~m} \times 12 \mathrm{~m}$ quadrants demarcated in each surface. The samples were selected systematically, (at every other quadrant) under cattle shed. A similar exercise was carried out at the adjacent fallow plot.

In each of the quadrats, composite soil samples were collected from a pre-determined depth of $0-15 \mathrm{~cm}$ and $15-30 \mathrm{~cm}$ referred to as the top soil and sub-soil respectively. This study confines analysis of soil characteristics to the top $30 \mathrm{~cm}$ of the soil profile because the roots of common crops in this area are usually concentrated in the top $30 \mathrm{~cm}$ of the soil profile where the bulk of plant nutrients are concentrated as reported by Oriola et $a l,(2010)$. This should be the zones best for the testing of soil fertility status.

Essential soil properties that directly affect the fertility status and productivity of the soils as observed by Brady and Weil (1999) were analysed. They include particle size composition, bulk density and water holding capacity, soil $\mathrm{pH}$, organic matter, organic carbon, total nitrogen, Phosphorus (ppm), exchangeable cations $\left(\mathrm{Ca}^{2+}, \mathrm{Mg}^{2+}, \mathrm{Na}^{+}, \mathrm{K}^{+}\right)$, cation exchange capacity and Base saturation.

Particle size analysis was carried out using ASTM D 422- the sieve and hydrometer analysis (Reddy, 2002). Bulk density was determined by core method of Black (1965) and Water holding capacity was determined by ASTM D 2216 standard test method for laboratory determinant of water content of soil, rock and soil aggregate(Reddy, 2002). The soil $\mathrm{pH}$ was determined using the glass electrode pH meter (Schofield and Taylor, 1955); Organic matter was determined by ASTM D 2974 - Standard Test Methods for Moisture, Ash, and Organic Matter of Peat and Organic Soils (Reddy, 2002). Total nitrogen was determined by Macro-kjedahl digestion distillation apparatus as described by Bremmer (1965); Available phosphorus (ppm) was determined using Bray No 1 method as described by Olsen and Dean (1965); exchangeable cations by the ammonium acetate method (Chapman 1965); cation exchangeable capacity of the soil is the 
summation of all the extractable bases and the percentage base saturation is the summation of total exchangeable bases expressed as a percentage of effective cation exchange capacity (Olajide, 2003).

Coefficient of variation was used to test the variability of the soil nutrients while student's ' $t$ ' - test was employed to test for the significant differences in the mean values of soil elements ( nutrients) in cattle shed and control plot. While fertility status of the soils under cattle shed surface was assessed in terms of the level organic matter and exchangeable bases.

\section{Results and Discussion}

Tables 1 and 2 show summary of soil properties of top soil and sub soil under cattle shed and adjacent fallow land surfaces respectively, while Table 3 shows the results of the T-test statistics depicting differences in soil properties between cattle shed and the fallow land surfaces in the study area.

The content of the particle size composition of the two sites differs. While the sand content is lower in the cattle shed site, the content of all other soil physical parameters are higher (table 1). The differences can be attributed to the influence of animal wastes on the soils in the cattle shed as observed by Zhang (1998). Furthermore, the capability of animal manure to increase infiltration of water and enhance nutrient retention has also been observed by Zhang (1998). In this study the water holding capacity is higher in the cattle shed soils $(23 \%)$ than in the adjacent fallow land $(19.96 \%)$

A comparative analysis of the cation content in the study sites with the documented soil test interpretation (Hazelton and Murphy,2007 and Marx et al, 1999) revealed that $\mathrm{K}^{+}, \mathrm{Mg}^{++}, \mathrm{Na}^{+}$have high values and $\mathrm{Mg}^{++}$ content is moderate. These same soil elements are rated low in the adjacent fallow land.

The result of the soil analysis carried out under the two-land used categories show no significant difference in the textural properties except for clay and silt which occur mainly on top soils and water Holding capacity in the sub soil (Table 3). The observation of the difference in the elements in the top and sub soils may be attributed to the effect of difference in textural class of the samples. Many authors have made observations that soil texture is a permanent property (Ogidiolu 1997; Gbadegesin and Olusesi, 1994) Thus, similarities in soil texture under the two landuse is justified. It also indicates that animal wastes do not affect soil texture significantly.

The organic matter content is higher in two lawyers of two surfaces but there exist a statistical difference between them (Table 3). The higher Organic matter content under cattle shed can be attributed to the fact that the method of initial site preparation does not involve the removal of cleared vegetation from the plot; therefore the organic matter is not lost from the plot, that the higher organic content in the soils of the cattle shed is due to the high amount of input received from cattle wastes and that the accumulated organic manure on the surface provides conducive environment for higher microbial activities (Simmons, 1972).

Similarly, other nutrients namely total nitrogen, available phosphorus, calcium and magnesium are also higher under the cattle shed (Table 1) and exhibit significant difference (Table 3). This pattern as observed by Olaitan and Lombin, (1988) confirmed that organic matter is a major indicator of soil nutrients due to its colloidal nature and the fact that it influences many other physical, chemical and biological properties of soil Reddy, 1999).

The mean value of the exchange potassium under cattle shed (Table 1) is more than that of the fallow land surface (Table 2). This higher value of potassium is due to additions through animal manure (Dung and Urine). Olaitan and Lombin (1988), reported that Organic waste is a good and dependable source of potassium, calcium and magnesium. The significantly higher concentration of exchangeable bases associated with organic wastes in agricultural soils have also been reported by Akponyoma, (1999).

The fairly high level of organic matter observed in the fallow land can be due to the humus formed by fallen leafs and dead plants decaying on the surface. The influence of 
animal manure from the cattle that occasionally traverse the site may also be responsible.

Soil reactions broadly reflect the extent to which the cation exchange capacity of the soil colloid is occupied by exchangeable cations. Soils of the study area are acidic but with increase in the exchangeable cation under cattle shed, soil acidity may decline. This condition is also conducive for optimum up take of nutrients for maximum plant growth. The mean level of cation exchange capacity is also higher under cattle shed than the fallow land in the study area. The presence of cattle dung and higher microbial activities in this area is responsible for the general changes observed.

Table 1 Descriptive Soil Properties under Cattle shed Surface (Top and sub soils)

\begin{tabular}{|c|c|c|c|c|c|c|c|c|c|}
\hline \multirow[b]{2}{*}{$\mathrm{S} / \mathrm{N}$} & \multirow{2}{*}{\begin{tabular}{|l|} 
Parameters \\
Physical properties \\
\end{tabular}} & \multicolumn{4}{|l|}{ Top Soil } & \multicolumn{4}{|l|}{ Sub Soil } \\
\hline & & Range & $\mathrm{X}$ & $\mathrm{SD}$ & $\mathrm{CV}$ & Range & $\mathrm{X}$ & $\mathrm{SD}$ & $\mathrm{CV}$ \\
\hline \multirow[t]{3}{*}{1} & $\begin{array}{l}\text { Particlesize distribution } \\
\text { Sand }\end{array}$ & $63.00-82.80$ & 67.46 & 3.60 & 5.33 & $58.80-83.40$ & 68.98 & 9.40 & 13.60 \\
\hline & Silt & $12.00-33.00$ & 21.07 & 2.57 & 9.70 & $7.0-35.40$ & 21.07 & 7.50 & 31.50 \\
\hline & Clay & $5.20-14.20$ & 9.61 & 0.65 & 0.01 & $5.80-21.20$ & 9.61 & 4.10 & 22.60 \\
\hline 2 & Bulk density & $0.86-1.030$ & 0.95 & 0.36 & $37.90 *$ & $0.86-1.03$ & 0.95 & 0.07 & $41.60 *$ \\
\hline \multirow[t]{2}{*}{3} & WHC & $22.05-26.00$ & 23.60 & 1.42 & 6.0 & $22.05-28.20$ & 25.30 & 2.30 & 9.00 \\
\hline & Chemical Properties & & & & & & & & \\
\hline 1 & $\mathrm{PH}$ & $5.82-6.65$ & 6.28 & 0.40 & 7.50 & $5.46-6.55$ & 6.16 & 0.37 & 6.00 \\
\hline 2 & Organic matter & $7.06-9.50$ & 8.09 & 0.76 & 9.30 & $6.3-8.20$ & 7.18 & 0.33 & 4.60 \\
\hline 3 & Total nitrogen & $1.77-2.70$ & 2.30 & 0.33 & 14.30 & $2.21-2.77$ & 2.39 & 0.29 & 12.10 \\
\hline 4 & Phosphorus (ppm) & $0.48-2.10$ & 1.12 & 0.60 & $53.50 *$ & $0.48-2.10$ & 1.23 & 0.63 & $51.20 *$ \\
\hline 5 & Exch. ca ${ }^{++}$meg/100\% & $2.21-8.70$ & 5.45 & 2.22 & $40.70 *$ & $3.20-6.13$ & 5.11 & 1.14 & 22.30 \\
\hline 6 & Exch.mg++ meg/100\% & $0.40-3.20$ & 1.73 & 0.90 & $52.00 *$ & $0.80-2.00$ & 1.52 & 0.35 & 22.30 \\
\hline 7 & Exch ka $^{+} \mathrm{meg} / 100 \%$ & $0.17-2.85$ & 1.51 & 0.80 & $52.90^{*}$ & $0.92-1.97$ & 1.59 & 0.33 & 20.70 \\
\hline 8 & Exch Na $^{+}$meg/100\% & $0.15-2.00$ & 1.07 & 0.60 & $56.00 *$ & $0.15-1.15$ & 0.53 & 0.37 & $69.80 *$ \\
\hline 9 & CEC & $7.02-13.15$ & 9.76 & 2.36 & 24.18 & $6.39-10.89$ & 8.70 & 1.16 & 13.40 \\
\hline 10 & Base saturation & $82.00-98.30$ & 81.38 & 5.60 & 6.12 & $84.60-94.10$ & 88.45 & 3.85 & 4.40 \\
\hline
\end{tabular}

$\begin{array}{llll}\text { C.V }>33 \% & \text { S.D }=\text { Standard Deviation } & \mathbf{X}=\text { Mean } \quad \text { C.V=Co-efficient of }\end{array}$ variation 
Table 2: Descriptive Soil Properties under Fallow land (Top and sub soils)

\begin{tabular}{|c|c|c|c|c|c|c|c|c|c|}
\hline & Parameters & & Top Soil & & & Sub & oil & & \\
\hline $\mathrm{S} / \mathrm{N}$ & Physical Properties & Range & $\mathrm{X}$ & S.D & C.V & Range & $\mathrm{X}$ & S.D & C.V \\
\hline 1 & Particle & & & & & & & & \\
\hline & Distribution & & & & & & & & \\
\hline & Sand & $62.3-82.40$ & 75.30 & 5.55 & 7.37 & $70.8-0.10$ & 75.90 & 3.31 & 4.36 \\
\hline & Silt & $9.00-21.00$ & 12.82 & 5.05 & $39.39 *$ & $15.0-19.0$ & 17.97 & 1.94 & 10.80 \\
\hline & Clay & $5.40-12.70$ & 7.47 & 2.03 & 27.18 & $5.10-8.40$ & 6.89 & 0.97 & 14.08 \\
\hline 2 & Bulk Density & $0.92-1.94$ & 1.20 & 0.28 & 23.33 & $0.66-1.62$ & 1.03 & 0.24 & 23.30 \\
\hline 3 & W H C & $19.2-23.00$ & 19.96 & 2.18 & 10.92 & $16.00-20.00$ & 18.26 & 1.59 & 8.71 \\
\hline & Chemical Properties & & & & & & & & \\
\hline 1 & $\mathrm{PH}$ & $5.18-6.01$ & 5.64 & 0.26 & 4.61 & $5.19-5.70$ & 5.45 & 0.20 & 3.67 \\
\hline 2 & Organic Matter & $1.62-3.12$ & 3.06 & 0.74 & 24.18 & $1.15-3.12$ & 2.01 & 0.74 & $36.82 *$ \\
\hline 3 & Total Nitrogen $\%$ & $0.52-1.12$ & 0.73 & 0.20 & 27.40 & $0.48-0.79$ & 0.63 & 0.11 & 17.46 \\
\hline 4 & Phosphorus (ppm) & $0.01-0.78$ & 0.45 & 0.25 & $55.56^{*}$ & $0.15-0.89$ & 0.52 & 0.24 & $46.15^{*}$ \\
\hline 5 & Exch.ca $^{++}$meg/100\% & $1.3-4.26$ & 2.74 & 1.03 & $37.59 *$ & $0.84-2.70$ & 1.72 & 0.64 & $88.89 *$ \\
\hline 6 & Exch.mg $^{++}$meg/100\% & $0.95-3.01$ & 1.54 & 0.59 & $38.31 *$ & $0.30-2.10$ & 1.25 & 0.67 & $56.60 *$ \\
\hline 7 & Exch.k $^{+}$meg/100\% & $0.40-0.89$ & 0.57 & 0.16 & 28.07 & $0.40-0.78$ & 0.52 & 0.14 & 26.92 \\
\hline 8 & Exch.Na ${ }^{+}$meg/100\% & $0.12-0.23$ & 0.16 & 0.04 & 25.00 & $0.11-0.17$ & 0.14 & 0.03 & 21.43 \\
\hline 9 & C E C & $0.95-2.36$ & 1.39 & 0.50 & 2.36 & $0.32-0.83$ & 0.67 & 0.21 & 13.40 \\
\hline 10 & Base Saturation & $82.10-92.20$ & 89.40 & 4.84 & 5.41 & $82.40-93.90$ & 85.40 & 8.83 & 10.34 \\
\hline
\end{tabular}

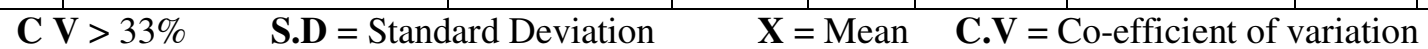

Table 3 T-Test Statistics Depicting Differences In Soil Properties Between Cattle Shed and Control field (Fallow land surface)

\begin{tabular}{|l|l|l|l|}
\hline & & Top Soil & Sub Soil \\
\hline $\mathbf{S} / \mathbf{N}$ & Physical Properties & & \\
\hline 1 & Particle size composition: & & \\
& Sand & -3.53 & -2.07 \\
& Silt & $4.40^{*}$ & 1.23 \\
& Clay & $2.97^{*}$ & 1.92 \\
\hline 2 & Bulk Density & -1.56 & -0.93 \\
\hline 3 & W H C & 1.92 & $7.48^{*}$ \\
\hline $\mathbf{S} / \mathbf{N}$ & Chemical properties & & \\
\hline 1 & PH & 0.75 & 0.56 \\
\hline 2 & Organic matter & $2.28^{*}$ & $1.97^{*}$ \\
\hline 3 & Total nitrogen $\%$ & $9.20^{*}$ & 0.21 \\
\hline 4 & Phosphorus $(\mathrm{ppm})$ & $3.04^{*}$ & $2.50^{*}$ \\
\hline 5 & EXch. Ca ${ }^{++}$meg/100\% & $2.79^{*}$ & $2.08^{*}$ \\
\hline 6 & EXch. $\mathrm{mg}^{++}$meg/100\% & $2.90^{*}$ & $2.11^{*}$ \\
\hline 7 & EXch. $\mathrm{K}^{+}$meg/100\% & $3.76^{*}$ & $3.34^{*}$ \\
\hline 8 & EXch. $\mathrm{Na}^{+}$meg/100\% & 0.60 & 0.37 \\
\hline 9 & C E C & $2.23^{*}$ & $2.92^{*}$ \\
\hline 10 & Base Saturation & -0.90 & $5.10^{*}$ \\
\hline
\end{tabular}

$*=$ T Calculated $>$ t. tabulated at tx $00.5 \%$ (6) significant level (1.94) 


\section{Study Implications}

The t-test results indicate that to a large extent there is a difference between both surfaces with respect to organic matter and other exchangeable bases. It thus implies that organic matter is highly influenced by the animal wastes (Dung and Urine) as these generate the litter that constitutes its major raw material. Furthermore, the balance of organic matter can also be easily influenced by biotic interference. Wastes from grazing animals can raise the level of organic matter by the addition of their dung while removal of plant cover through various processes like bush burning and animal grazing as it is the case in the noncattle shed site of the study area could bring imbalance. This is the observation in this study.

The study also implies that the difference in organic matter and other exchangeable bases can therefore be justified by the variation in the major chemical properties of the soils in this area. Since the high concentration of the chemical elements and organic matter determine fertility status of soil, it thus implies that fertility status of soil in the study area improves better in cattle shed soils than the non-cattle shed land.

This occurrence calls for the awareness on adoption of mixed farming in this area and other similar environment. An abandoned cattle shed can enhance a better yield. This will improve the economy by reducing cost on fertilizer and increasing food production. This issue of mixed farming is very important because depletion of soil nutrients often leads to clearing new forest thereby extending agricultural land. Besides, it will also help in reducing the persistent sought for fertilizer by farmers.

Since organic manure has been detected to improve soil fertility significantly, other forms of organic wastes such as poultry wastes and organic domestic wastes can be utilized to regenerate soil. This can be achieved by dumping such materials on degraded soils. This will be a good way of material recycling.

The Fulani nomads should be made to colonize a degraded soil environment. This will help in its reclamation within a short time. This will make more land available to agricultural sector to increase food production for the higher demand of the rapid increasing population.

\section{Conclusion}

The high varying nature of soil nutrients and organic matter properties between cattle shed and adjacent fallow land surfaces in the study area is likely to bring about varying degree of soil productivity in this area. This is because the soil properties that exhibit variability were the ones that are essential to plants and they were required in large quantities for growth and development of plants and their productivity. The importance of proper monitoring of soil variables lies in its influence in detecting the spatial and temporal trend of a particular soil use. Such an evaluation will reveal whether soil physical and chemical properties is deteriorating or improving.

\section{References}

Aina, P.O. (1982), Influence of Exchangeable cation on the physical properties of Ngala soil from Northern Nigeria. Nigerian Journal of Agricultural Science, 4(2), 45 - 48. Akinbode, A. (1986), "Imperative for Rural Development in Nigeria" In Adeniyi; E.O.and Bello - Immam, I.B. (eds) Development and the Environment. Proceeding of a National Conference. NISER, Ibadan, Nigeria.

Akponyoma, C.A. (1999), Comparison of Properties o f urban and Agricultural soils in Ibadan. Unpublished BSc. Dissertation, Department of Geography and Regional Planning, University of Benin."

Aweto, A.O. (1981), "Organic Matter build up on fallow soils in a part of south - western Nigeria and its effect on soil properties" Journal of Soil Science, 8, 67-74.

Black G. R. (1965), "Bulk Density" in Black C. A. (ed) Methods of Soil Analysis, 1, 374390 A. S. A . Madison Wisconsin.

Brady, N.C. and Weil, R.R. (1999), The Nature and properties of soil. $\left(12^{\text {th }}\right.$ Edition) Prentice Hall, New Jersey.

Bremmer, J.M. (1965), "Total Nitrogen" in Black, C. A. (eds) Methods of soil Analysis. American Society of Agronomy Monograph, 9, (2) 162-164. 
Chapman, H.D. (1965), "Cation Exchange" in Black, C. A. (eds) Methods of Soil Analysis .America soil of Agronomy Monograph, 9(2) 891-901.

F.A.O. (2000), Food and Agricultural Organization. http//faostat.fao.org.

Gbadegesin, A. S. and Olusesi, B, B. (1994):

"Effects of Land clearing Methods on an Alfisol in South Western Nigeria". The Indonesia Journal of Geography. 26:41-45.

Hazelton, P. and Murphy, B. (2007), Soil Chemical Properties. Interpreting Soil Test Results, What Do all Numbers mean? SCIRO Jeje, O.G. (2011), Climate Change, Perception and Response in Asa Local Government Area of Kwara state. Unpublished M.Sc. dissertation Department of Geography and Environmental Management, University of Ilorin, Ilorin.

Kwara State Ministry of Land and Housing (2003).

Marx, E.S., Hart, J. and Stevens, R.G. (1999), Soil Test Interpretation Guide EC1478 Oregon State University Extension Service.

Nwinyi, S.C.O. (1981), "Soil fertility improvement under fallows of selected Grass/Legume Association". Nigeria Journal of Agricultural Science. Vol. 2 pp 167-171.

Ogidiolu , A. (1997), "Effect of cassava cultivation on soil properties under peasant farming system in south-western Nigeria". International Journal of Environment and Development, 1, 25-29.

Olajide, O.J. (2003), "Evaluation of the soil map of Nigeria for land use planning in Kwara State." Unpublished Ph. D Thesis, Department of Agriculture and Forestry, University of Ibadan, Ibadan, Nigeria.

Oriola, E.O. (2004), "Dynamics of soil chemical properties in Oke-oyi irrigation project site of the lower Niger River Basin Development Authority, Ilorin, Nigerian". Geo Studies forum. An International Journal of Environmental and Policy Issue, 2(1), 86-93.
Oriola, E.O., Ifabiyi, I. P., and Hammed, A.T. (2010), Impact of reforestation in a part of degrading natural ecological system of Ilorin, Kwara State, Nigeria. African Journal of Agricultural Research, 5(20) : 811-2816, Published by Academic Journals www.academicjournals.org/AJAR.

Oyebanji, J.O. (1993), "Kwara State"in Udo, R.K. and Mamman, A.B. (eds) Nigeria Giant in the Tropics. State Survey, Gabumo Publishing Co. Lagos, Nigeria.

Oyegun, R. (1983), Water Resources in Kwara State, Nigeria. Matanmi \& Sons, Ilorin, Nigeria. pp 154.

Olsen, S.R. and Dean, L.A. (1965): "Phosphorus" in Black, C.A. (eds) Methods of soil Analysis. Amer. Soc. Agronomy Monograph, 9 (2), 1035-1048.

Olaitan, S. O. and Lombin, G. (1988): Introduction to Tropical Soil Science. Macmillan Hong Kong pp 126.

Reddy, K.R.(1997), Laboratory Testing of Soils for Engineering Purposes, Laboratory Manual, University of Illinois at Chicago, (available at: www.uic.edu/classes/cemm/cemmlab/).

Reddy, K.R., (2002), Engineering Properties of Soils based on Laboratory Testing. Department of Civil and Material Engineering, University of Illinois. Chicago (available at: www.uic.edu/classes/cemm/cemmlab/). Pp.1159

Simmons, N.W. (1972), The Evolution of the Bananas, Longman Publication, London. Pp 48.

Schofield, R.K. and Taylor, W. (1955), "The measurement of soil PH" Soil Science. Amer. Proceeding, 10, 164-167.

Zhang, H. (1998), Fertilizer Nutrients in Animal Manure . F-2228 Oklahoma Cooperative Extension Fact Sheets. Division of Agricultural Science and Natural Resources. Oklahoma State University 